\title{
Food web bioaccumulation of organohalogenated compounds in high mountain lakes
}

\author{
Mireia Bartrons ${ }^{1,2, *}$, Joan O. Grimalt ${ }^{3}$ and Jordi Catalan ${ }^{2}$ \\ 1 Center for Limnology, University of Wisconsin, Madison, 680 N. Park St. Madison, WI 53706, USA. \\ ${ }^{2}$ Limnology Unit (CSIC-UB). Centre for Advanced Studies of Blanes (CEAB-CSIC). Accés Cala St. Francesc, \\ 14. 17300 - Blanes, Catalonia, Spain. \\ ${ }^{3}$ Department of Environmental Chemistry (IIQAB-CSIC). Jordi Girona, 18. 08034-Barcelona, Catalonia, Spain. \\ *Corresponding author: bartrons@wisc.edu
}

Received: $2 / 1 / 2012$

Accepted: $30 / 1 / 2012$

\begin{abstract}
Food web bioaccumulation of organohalogenated compounds in high mountain lakes

Persistent organic pollutants (POPs) are toxic substances that are usually produced for use in agricultural, industrial, and domestic applications. Because of their long-range atmospheric transport capacity, POPs are distributed worldwide. The global distillation theory predicts that there will be a temperature-dependent partitioning of these low volatility compounds in the environment. Concentration patterns of POPs in agreement with the theory have been observed for different environmental compartments, such as lake sediments and mosses, and along altitudinal and latitudinal gradients. However, concentration patterns in lake fish do not exactly match the expected results, indicating that further investigation into the bioaccumulation processes in food webs is required. Here, we briefly review the state of the question of POPs bioaccumulation in high mountain lake food webs and present some hypotheses concerning processes worthy of investigation.
\end{abstract}

Key words: Persistent organic pollutants, organochlorinated compounds, PBDEs, bioaccumulation, food webs, high mountain lakes, altitudinal gradient.

\section{RESUMEN}

Bioacumulación de compuestos organohalogenados en redes tróficas de lagos de alta montaña

Los contaminantes orgánicos persistentes (POPs) son sustancias producidas para usos agrícolas, urbanos o industriales que presentan un carácter tóxico. Debido a la capacidad de transporte atmosférico a largo alcance, los POPs son distribucidos por todo el mundo. La teoría de la Destilación Global propone una distribución de estos compuestos de baja volatilidad en el medio ambiente dependiente de la temperatura del aire. Se ha observado este fenómeno en distintos compartimentos ambientales situados a lo largo de gradientes de altitud o latitud, como por ejemplo en sedimentos de lagos o en musgos. Sin embargo, algunas de las pautas observadas en peces no responden a lo esperado y ponen de relieve la falta de un conocimiento suficiente sobre la transferencia de estos contaminantes en las redes tróficas. Aquí se hace una breve revisión del estado de la cuestión sobre la bioacumalación de compuestos orgánicos persistentes en lagos de montaña y se sugieren algunas hipótesis sobre posibles procesos a investigar.

Palabras clave: Compuestos orgánicos persistentes, organoclorados, PBDEs, bioacumulación, redes tróficas, lagos de alta montaña, gradiente altitudinal. 


\section{PERSISTENT ORGANIC POLLUTANTS}

Persistent organic pollutants (POPs) are generally halogen-substituted toxic hydrocarbon molecules that have a cyclic or aromatic structure (Fig. 1). They are semi-volatile, highly hydrophobic and degrade slowly under natural conditions. They are produced for agricultural, urban, and industrial applications. Because of these characteristics, they can be atmospherically transported long distances and bioaccumulate in organisms. Many POPs are distributed widely across the earth, including in regions where they have never been used (Wania \& Mackay, 1993; Simonich \& Hites, 1995). Due to their toxicity, they can pose a threat to humans and the environment. For instance, biomagnification exposes animals from the top food web positions to doses which may cause endocrine disruption, altered neurological development, immune system modulation, and cancer (Who, 2003).

The use of POPs began with the growth of the organic chemical industry in the early 20th century; dichlorodiphenyltrichloroethane (DDT) was the first POP synthesised in 1874. As the use of halogenated, particularly chlorinated, organic chemicals rose in agricultural and industrial sectors, so did concern about potential adverse consequences to human health and the environment. In 1962, a turning point occurred
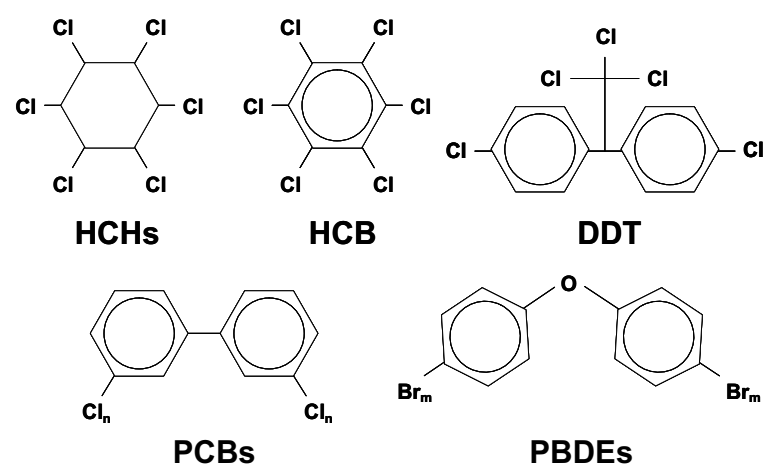

Figure 1. Chemical structure of hexachlorocyclohexanes (HCHs), hexachlorobenzene (HCB), dichlorodiphenyltrichloroethane (DDT), polychlorobiphenyls (PCBs) and polychlorodiphenyl ethers (PBDEs). Estructura de los hexaclorociclohexanos (HCHs), hexaclorobenceno (HCB), diclorodifeniltricloroetano $(D D T)$, bifenilos policlorados (PCBs) y polibromodifenil éteres (PBDEs). with the publication of Rachel Carson's Silent Spring (Carson, 1962). Through her book and the accompanying media attention, the general public first became aware of a downside to the proliferation of chemicals.

The first global regulation to outlaw, limit the use of or curtail the inadvertent production of POPs was agreed in the Stockholm Convention on Persistent Organic Pollutants in May 2001 and entered into force on May 2004. Twelve groups of substances, known as the dirty dozen, were initially included. All of the compounds exhibited prolonged environmental persistence, bioaccumulation, high toxicity, and the potential for long-range environmental transport.

\section{GLOBAL DISTILLATION THEORY}

The atmosphere is the main route of dispersal of POPs far from centers of human population (Eisenreich \& Strachan, 1992). Once in the environment, they cycle and partition between major environmental compartments. Due to their semivolatile character (vapour pressure between $10^{-4}$ and $10^{-11}$ atm at $25^{\circ} \mathrm{C}$ ), the compounds also partition between the atmospheric gas and aerosol phases (Duinker \& Bouchertall, 1989; Aceves \& Grimalt, 1993; Kaupp \& McLachlan, 1999) (Fig. 2). Association with atmospheric particles increases their removal rate from the atmosphere by dry and wet deposition processes, which ultimately limits the distance they travel from their sources. Thus, removal from the atmosphere occurs by dry deposition of particulate-bound pollutants, diffusive gas exchange between atmosphere and water surfaces, and scavenging by rain (wet deposition) (Fig. 2). In addition, during atmospheric transport, POPs can undergo a number of processes that will determine their fate in the global environment, such as degradation, deposition to soils, vegetation or water bodies, revolatilisation, sedimentation, and bioaccumulation (Fig. 2). The significance of each of these processes depends on the climatic conditions and the physico-chemical properties of each compound.

Cold regions retain POPs as a result of temperature-dependent partitioning between gas, 


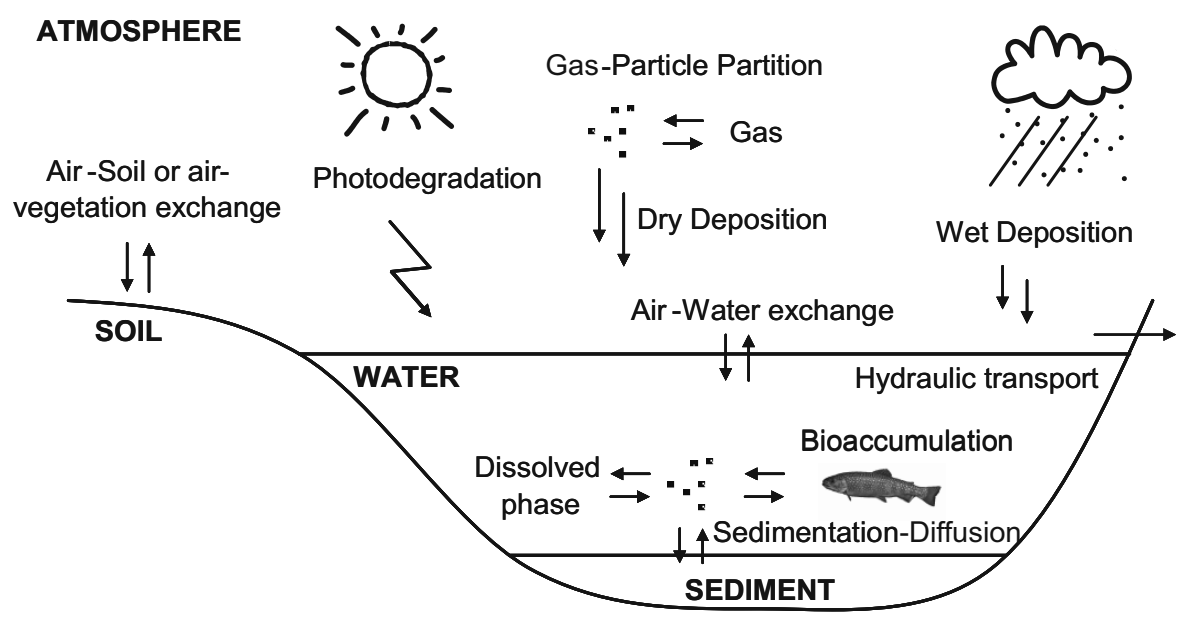

Figure 2. Main environmental processes occurring during long-range atmospheric transport of POPs. Adapted from Fernández \& Grimalt (2003). Principales procesos ambientales que ocurren en la atmósfera durante el transporte de los contaminantes orgánicos persistentes a larga distancia. Adaptado de Fernández \& Grimalt (2003).

water and particles during long-range transport. The whole process is known as the global distillation theory (Wania \& Mackay, 1993; Wania \& Mackay, 1996). POPs have been found at significant concentrations at high latitudes (Kidd et al., 1998) and altitudes (Blais et al., 1998; Grimalt et $a l ., 2001)$. The global distillation theory is based on the shift in phase distribution equilibrium of semi-volatile chemicals from the atmospheric gas phase to the earth's surface with decreasing temperature. As a consequence, the theory predicts a process of global fractionation in which or-

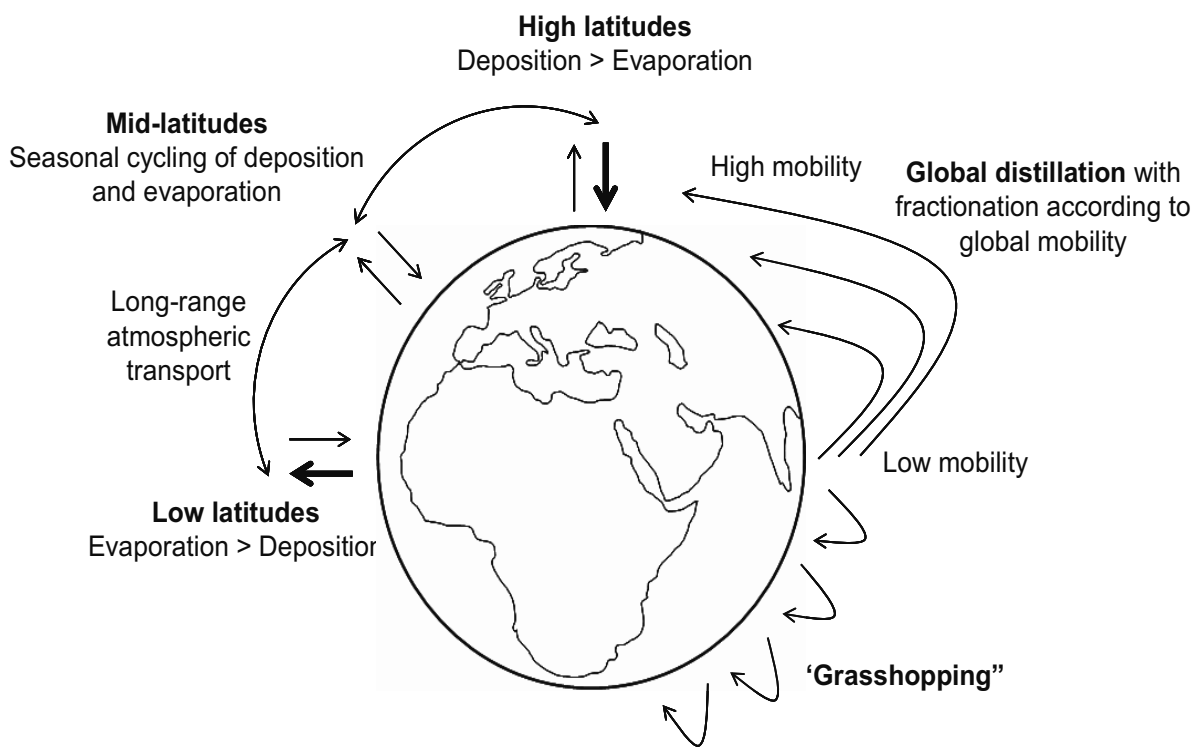

Figure 3. POP migration processes. Global deposition processes become more pronounced than evaporation at high latitudes and lower temperatures. Adapted from Wania \& Mackay (1996). Procesos de migración de POP. Los procesos globales de deposición son más pronunciados que los de evaporación en las latitudes altas y temperaturas bajas. Adaptado de Wania y Mackay (1996). 
ganic compounds become latitudinally and altitudinally fractionated, "condensing" at different ambient temperatures according to their volatility. Transport to colder regions can, at least in part, occur via repeated cycles of deposition and evaporation driven by seasonal, frontal, and diurnal changes in temperature; this is known as grasshopping transport (Fig. 3).

However, in mountains, which are characterised by a gradient of temperature from low to high altitudes, the preferential accumulation of organic pollutants is different from the one produced between low and high latitudes (Grimalt et al., 2001; Fernandez \& Grimalt, 2003). Substances accumulating in mountains are approximately two orders of magnitude less volatile than the substances that experience latitudinal cold trapping. Wania \& Westgate (2008) proposed that this phenomenon is produced by differences in the efficiency of precipitation scavenging at various elevations, which in turn is caused by the temperature dependence of organic vapour partitioning into rain, snow, and aerosols.

\section{FOOD WEB BIOACCUMULATION OF ORGANOHALOGEN COMPOUNDS}

Bioaccumulation is a process in which the concentration of a chemical in an organism increases compared to the concentration in the environment over time. It can occur directly from exchange with the media (bioconcentration) or by feeding (biomagnification) (Thomann, 1981). Bioaccumulation eventually results from the balance between uptake, via dietary ingestion and respiration, and loss, via growth dilution, respiration, metabolism, and faecal egestion (Campfens \& Mackay, 1997).

Most POPs and natural compounds that have a tendency to biomagnify in food webs are neutral organic compounds that are highly substituted (or substituted at critical positions in the molecule) with chlorine or bromine. These properties make them lipophilic and not easily metabolised. Their lipophilic nature ensures their efficient uptake from the diet and storage in fat depots, and the halogens prevent attack by enzymes. The flux of depuration of the unchanged compound (mainly via gill loss) is generally slower than the rate of uptake (mainly via gut uptake) for highly lipophilic compounds (Catalan et al., 2004), thus the concentration in the organism may become higher than would be expected from a thermodynamic equilibrium after achieving a steady state of the input and output fluxes of the pollutant.

The bioaccumulation potential of organic chemicals is often compared to the octanol-water partition coefficient $\left(K_{\mathrm{OW}}\right) . K_{\mathrm{OW}}$ is the ratio of the concentration of a chemical in octanol to its concentration in water at equilibrium at a specified temperature (Mackay, 1982). It indicates the hydrophobicity of a chemical and how it thermodynamically distributes between the aqueous and organic phases. In aquatic food webs, only hydrophobic, fat-soluble chemicals with octanol-water partition coefficients greater than 100000 are bioaccumulated. In contrast, poorly metabolised, moderately hydrophobic substances with a $K_{\text {OW }}$ between 100 and 100000 do not biomagnify in aquatic food webs. However, they can biomagnify in food webs containing airbreathing animals (including humans) to a high degree because of their high octanol-air partition coefficient $\left(K_{\mathrm{OA}}\right)$ and a corresponding low rate of respiratory elimination to air.

Various conceptual models have been used over the years to describe the toxicokinetics of organohalogen compounds. The simplest treatment of uptake is to multiply the feeding rate by the concentration of organohalogen compound in food and by the efficiency of uptake of the organism. There are numerous examples of feeding studies in the literature showing that the uptake efficiency of organohalogen compounds from the diet is high, presumably because the efficiency of lipid uptake is also high. This simple approach was accepted for many years until it was called into question by a theory that proposed that absorption is driven by diffusion of organohalogen compounds between the gut content and the organism (Gobas et al., 1993). Within this theory, food absorption is expected to "magnify" the chemical concentration in the food, thus raising the diffusion between the gut content and the organism internal media. 
In birds and mammals, the fugacity gradient model of Gobas et al. (1993) does not fit particularly well with what is known about the physiology of lipid absorption in these organisms. For instance, studies in kestrels (Falco sparverius) and ring doves (Streptopelia risoria) showed that uptake of organohalogen compounds occurs in the upper gut through the same mechanism by which lipids are absorbed (Drouillard \& Norstrom, 2000). The process is driven by diffusion of lipid-containing micelles through the epithelial wall of the upper gut. The mechanism is very efficient and not highly dependent on $K_{\text {Ow }}$. Once absorbed, distribution of organohalogen compounds among the various lipid pools in the body occurs relatively quickly. Circulating organohalogen compounds are excreted slowly into the lower gut via a fugacity gradient-driven process, which is highly dependent on the log $K_{\text {Ow }}$ of the compound and metabolism. This phenomenon likely applies to all birds and mammals, but it is not clear whether it also applies to fish and other ectothermic organisms, such as invertebrates, where lower body temperatures may slow diffusion rates and decrease the bioavailability of high $K_{\text {Ow }}$ organohalogen compounds.

In summary, there is evidence that not all organisms bioaccumulate organohalogen compounds in the same way. The organisms' size, age, lipid content, metabolic rate and biotransformation capacity are some of the factors that influence bioaccumulation rate the most. For example, the concentrations of lipophilic and persistent organochlorines are orders of magnitude higher in endotherms than in ectotherms as a result of the different energy requirements, bioaccumulation procedures (as described previously), and biotransformation abilities (Hop et al., 2002). Furthermore, the bioaccumulation of organohalogen compounds is less understood in organisms of lower trophic levels. For instance, the biotransformation capacity of different organisms, the importance of their feeding habits and behaviour, and the influence of environmental variables such as temperature on the biomagnification of organohalogen compounds by aquatic macroinvertebrates is not well resolved at present.

\section{HIGH MOUNTAIN LAKES}

Remote mountain regions are increasingly affected by anthropogenic influences, despite being situated above the tree line in areas that are rarely disturbed by agriculture, forestry, and human settlement. Recent research indicates that even the most remote lakes in Europe contain atmospherically transported pollutants, and evidence is growing that climate change is beginning to have a significant impact on them (Battarbee, 2005). In particular, alpine lake ecosystems are especially sensitive to external forcing because their small catchments in relation to the lake area make atmospheric loading more relevant in their dynamics. This feature and their remoteness from areas of high human activity make alpine lakes excellent sentinels and recorders of past and present global changes (Catalan et al., 2006). However, most previous studies focused on a reduced number of organisms or on specific ecological compartments (e.g., phytoplankton, zooplankton, fish, etc.). There is still insufficient knowledge of high mountain lake food webs and how they change with increasing altitude.

Because temperature is a determinant of the distribution of organochlorine compounds along altitudinal profiles (Blais et al., 1998; Carrera et al., 2001; Grimalt et al., 2001; Ribes et al., 2002), high mountain lakes are excellent settings to study the processes involved in the "global distillation theory". The transport of organohalogen compounds in mountains has been well documented. They have been found in snow (Blais et al., 1998; Carrera et al., 2001), sediment (Grimalt et al., 2001), mosses (Grimalt et al., 2004), amphipods (Blais, 2003) and fish ...(Grimalt et al., 2001; Vives et al., 2004; Demers et al., 2007; Gallego et al., 2007), and the concentration of organichlorine (OC) and polybromodiphenyl ether (PBDE) compounds increased with elevation.

\section{BIOACCUMULATION OF OCS AND PBDES IN HIGH MOUNTAIN LAKE FOOD WEBS}

The distribution patterns of persistent organic pollutants along mountain altitudinal profiles 
are in agreement with the prediction of a temperature-dependent partitioning of low volatile compounds by the global distillation theory (Wania \& Mackay, 1993; Wania \& Mackay, 1996). However, in several studies on mountain lake fish (Vives et al., 2004; Demers et al., 2007; Gallego et al., 2007), the altitudinal patterns found do not fully agree with the POPs theoretical phase-change enthalpies. In some cases (Vives et al., 2004), the pseudo-enthalpies are two-fold higher than those found for sediments. Therefore, investigating the food web bioaccumulation of halogenated compounds in high mountain lakes could provide new clues about the mechanisms involved in bioaccumulation processes and their temperature dependence.

\section{Food web trophic structure}

Determining the food web structure is a necessary first step to understand the bioaccumulation of POPs in food webs. Therefore, stable isotopes from organic $\mathrm{C}$ and $\mathrm{N}$ in the main food web organisms should be analysed. Bartrons et al. (2010) showed that variability in ${ }^{15} \mathrm{~N}$ was high in the initial sources of food web nitrogen (dissolved ammonium and nitrate). Nitrogen deposition in remote areas has increased, but the effect on ecosystems is still poorly understood. Differences in dissolved inorganic nitrogen (DIN) between lakes cannot be understood without considering catchment characteristics. In mountains, catchment features (e.g., thermal conditions and land cover features) vary considerably with elevation. According to Bartrons et al. (2010), lakes with a greater snow-type influence will most likely register changes in $\mathrm{N}$ deposition and pollution sources better, whereas lakes with higher soil-type influence may reflect the longterm effects of vegetation and soil dynamics. Due to this high isotopic variation in the initial nitrogen sources and the in-lake habitat variability, we can expect large variation in the $\delta^{13} \mathrm{C}$ and $\delta^{15} \mathrm{~N}$ values within (i.e., littoral/bottom) and between (i.e., montane/alpine) lake food webs. The nature and availability of the $\mathrm{N}$ sources for primary producers and the omnivory in these oligotrophic systems could turn out to be crucial to explain the patterns. Alternately, the existence of this variability without major differences in food web composition among lakes suggests that $\delta^{15} \mathrm{~N}$ values are suitable for monitoring and evaluating the increase in nitrogen deposition as a component of global change.

\section{Trophic position as a bioaccumulation factor}

How important is trophic position in determining the amount of OCs in an organism compare to other factors? Does the importance of trophic position change according to the characteristics of the compound (e.g., $K_{\mathrm{OW}}$ )? Does temperature have any other additional effect beyond its role in setting the initial concentrations in water? How do trophic factors compare with other traditional factors, such as lipid content? Lipid content is a key factor introducing variation among individuals of the same species, but is it still relevant when comparing small organisms of different trophic levels?

Do all types of organohalogen compounds behave similarly in food webs? For instance, PBDEs are less biologically recalcitrant than the correspondent PCBs because they have a structure similar to that of secondary metabolites from marine and terrestrial plants and animals (Kicklighter et al., 2004; Teuten et al., 2005). Perhaps PBDE and other organic pollutants are biotransformed in food webs more than was commonly assumed. The evolutionary trophic history of each group could modulate the ability of each organism to handle the pollutants. Organisms that experience frequent allelochemical interactions might as a result be better adapted to biotransform PBDEs than those without such a situation throughout their evolutionary history (e.g., clades of secondary consumers).

\section{Metamorphosis and metabolism}

The occurrence of different metabolic states during the metamorphosis of aquatic insects (e.g., pupa vs. larva) is also an important factor in the bioaccumulation of OCs and PBDEs in food webs. For instance, weight loss by pupae during metamorphosis resulting from protein carbon ox- 
idation and lack of feeding produced increased pollutant concentrations during metamorphosis (Bartrons et al., 2007).

Metabolism should also be considered in the context of the concentration changes of POPs in food web organisms from lakes located along altitudinal gradients. PCBs are good candidates for investigating the metabolic aspects of bioaccumulation. The concentrations of PCBs found in the first trophic positions along the altitudinal gradient should follow a similar trend to that found in sediments, with concentration increasing with altitude. However, if metabolism is controlling the bioaccumulation throughout the food web and temperature is controlling metabolism, the rate of pollutant increase (slope) with altitude should be lower the higher the trophic position of a species. This is because ectothermic organisms have lower energetic requirements with decreasing temperature and consequently have lower food intake and respiration. If this is the case, it implies that the food web does not have any direct influence on the altitudinal amplification of organohalogen compounds found in fish (Grimalt et al., 2001; Vives et al., 2004; Demers et al., 2007; Gallego et al., 2007). Physiological and behavioural studies are needed to understand the observed altitudinal trends of organohalogen compounds in fish. For instance, recent findings suggested that fish have different capacities to biotransform PCBs depending on the water temperature (Buckman et al., 2007). A better understanding of organohalogen compound transmission from brown trout females to their eggs and the bioaccumulation in the succeeding developmental stages (fry, juvenile and adult fish) would be useful to clarify the temperature dependence of bioaccumulation of organohalogen compounds by fish.

\section{The challenge of microenvironments}

A lot of biological activity in mountain lakes occurs microbiologically at microsites. The features of the environment in these sites may significantly different from that in the main water column. At lower altitudes with higher temperatures and prolonged growing seasons lake pro- ductivity is higher. In particular, thicker biofilms develop, which increases the probability of finding anaerobic microenvironments. Recently, we found that these sites are extremely important for the microbial degradation of PBDEs (Bartrons $e t$ al., 2011), which is enhanced in anaerobic environments (Gerecke et al., 2005; He et al., 2006; Vonderheide et al., 2006). As a consequence of the change in the availability of these anaerobic microsites, a strong gradient in the concentration of PBDEs in rock, sand and fine sediment biofilms was found throughout the altitudinal gradient. These results suggest that in addition to the global distillation effect, enhancement or depletion of biodegradation may be relevant for the assessment of the global distribution of these compounds at a planetary scale.

\section{CONCLUSION}

Food web bioaccumulation of persistent organic pollutants in mountain lakes is a consequence of multiple factors: the intrinsic features of the organisms, such as their developmental stage or their metabolic activity in relation to their trophic position; the external factors related to lake altitude, which in turn affect the metabolic activity of the organisms; and the behaviour of POPs in the environment (Wania \& Mackay, 1993; Wania \& Mackay, 1996). Both the presence of POPs in these remote systems, located far away from their emission sites, and the temperature variation associated with the altitudinal gradient, which can be used to simulate climate change scenarios, are important aspects of the global change occurring on earth. Thus, high-mountain lake food webs are suitable for monitoring the effects of global change, especially those related to the toxification of nature by persistent organic pollutants. The location of high-mountain lakes far from centres of human population, their position along large altitudinal gradients without other major changes in the main lake characteristics, the simplicity of their food webs and, overall, their sensitivity to external forcing, make them excellent sentinels and recorders of present and past global changes. 


\section{ACKNOWLEDGEMENTS}

This work has been supported by the EU Project Euro-Limpacs (GOCE-CT-2003- 505540), Spanish MEC project Trazas (CGL2004-02989) and Consolider Ingenio "GRACCIE" program (CSD2007-00067). Field, technical and discussion help from L. Camarero, G. de Mendoza, M. Bacardit, M. Altuna, D. Díaz de Quijano, C. Rivera, J. Arola, P. Fonollà, S. Orgué, C. Bosch, E. Gallego, R. Fonts, D. Carrizo, R. Quiroz, I. Vives, P. Fernández, J. López, R. Mas, R. Franco, E. Martí, E. Gacia, E. Casamayor, E. Ballesteros and N. Raventós is acknowledged.

\section{REFERENCES}

ACEVES, M. \& J. O. GRIMALT. 1993. Seasonally dependent size distributions of aliphatic and polycyclic aromatic-hydrocarbons in urban aerosols from densely populated areas. Environ. Sci. Technol., 27(13): 2896-2908.

BARTRONS, M., L. CAMARERO \& J. CATALAN. 2010. Isotopic composition of dissolved inorganic nitrogen in high mountain lakes: variation with altitude in the Pyrenees. Biogeosciences, 7: 14691479.

BARTRONS, M., J. O. GRIMALT \& J. CATALAN. 2007. Concentration changes of organochlorine compounds and polybromodiphenyl ethers during metamorphosis of aquatic insects. Environ. Sci. Technol., 41(17): 6137-6141.

BARTRONS, M., J. O. GRIMALT \& J. CATALAN. 2011. Altitudinal distributions of BDE-209 and other polybromodiphenyl ethers in high mountain lakes. Environ. Pollut., 159: 1816-1822.

BATTARBEE, R. W. 2005. Mountain lakes, pristine or polluted? Limnetica, 24(1-2): 1-8.

BLAIS, J. M. 2003. Concentrations of organochlorine pesticides and polychlorinated biphenyls in amphipods (Gammarus lacustris) along an elevation gradient in mountain lakes of western Canada. Environ. Toxicol. Chem., 22(11): 2605-2613.

BLAIS, J. M., D. W. SCHINDLER, D. C. G. MUIR, L. E. KIMPE, D. B. DONALD \& B. ROSENBERG. 1998. Accumulation of persistent organochlorine compounds in mountains of western Canada. Nature, 395 585-588.
BUCKMAN, A. H., S. B. BROWN, J. SMALL, D. C. G. MUIR, J. PARROTT, K. R. SOLOMON \& A. T. FISK. 2007. Role of temperature and enzyme induction in the biotransformation of polychlorinated biphenyls and bioformation of hydroxylated polychlorinated biphenyls by rainbow trout (Oncorhynchus mykiss). Environ. Sci. Technol., 41: 3856-3863.

CAMPFENS, J. \& D. MACKAY. 1997. Fugacitybased model of PCB bioaccumulation in complex aquatic food webs. Environ. Sci. Technol., 31: 577583.

CARRERA, G., P. FERNANDEZ, R. M. VILANOVA \& J. O. GRIMALT. 2001. Persistent organic pollutants in snow from European high mountain areas. Atmos. Environ., 35(2): 245-254.

CARSON, R. 1962. Silent Spring. Boston Houghton Mifflin. 378 pp.

CATALAN, J., L. CAMARERO, M. FELIP, S. PLA, M. VENTURA, T. BUCHACA, F. BARTUMEUS, G. DE MENDOZA, A. MIRÓ, E. O. CASAMAYOR, J. M. MEDINA-SÁNCHEZ, M. BACARDIT, M. ALTUNA, M. BARTRONS \& D. DÍAZ DE QUIJANO. 2006. High mountain lakes: extreme habitats and witnesses of environmental changes. Limnetica, 25(1-2): 551-584.

CATALAN, J., M. VENTURA, I. VIVES \& J. O. GRIMALT. 2004. The roles of food and water in the bioaccumulation of organochlorine compounds in high mountain lake fish. Environ. Sci. Technol., 38: 4269-4275.

DEMERS, M. J., E. N. KELLY, J. M. BLAIS, F. R. PICK, V. L. ST LOUIS \& D. W. SCHINDLER. 2007. Organochlorine compounds in trout from lakes over a 1600 meter elevation gradient in the Canadian Rocky Mountains. Environ. Sci. Technol., 41(8): 2723-2729.

DROUILLARD, K. G. \& R. J. NORSTROM. 2000. Dietary absorption efficiencies and toxicokinetics of polychlorinated biphenyls in ring doves following exposure to Aroclor (R) mixtures. Environ. Toxicol. Chem., 19(11): 2707-2714.

DUINKER, J. C. \& F. BOUCHERTALL. 1989. On the distribution of atmospheric polychlorinated biphenyl congeners between vapor-phase, aerosols, and rain. Environ. Sci. Technol., 23: 5762.

EISENREICH, S. J. \& W. M. J. STRACHAN. 1992. Estimating atmospheric deposition of toxic substances to the great lakes-an update. Burlington, 
Ontario, Proc. workshop Canada centre for inlands waters. $59 \mathrm{pp}$.

FERNANDEZ, P. \& J. O. GRIMALT. 2003. On the global distribution of persistent organic pollutants. Chimia, 57: 514-521.

GALLEGO, E., J. O. GRIMALT, M. BARTRONS, J. F. LOPEZ, L. CAMARERO, J. CATALAN, E. STUCHLIK \& R. W. BATTARBEE. 2007. Altitudinal gradients of PBDEs and PCBs in fish from European high mountain lakes. Environ. Sci. Technol., 41: 2196-2202.

GERECKE, A. C., P. C. HARTMANN, N. V. HEEB, H. P. E. KOHLER, W. GIGER, P. SCHMID, M. ZENNEGG \& M. KOHLER. 2005. Anaerobic degradation of decabromodiphenyl ether. Environ. Sci. Technol., 39: 1078-1083.

GOBAS, F. A. P. C., X. ZANG \& R. WELLS. 1993. Gastrointestinal magnification: the mechanism of biomagnification and food chain accumulation of organic chemicals. Environ. Sci. Technol., 27: 2855-2863.

GRIMALT, J. O., F. BORGHINI, J. C. SANCHEZHERNANDEZ, R. BARRA, C. J. T. GARCIA \& S. FOCARDI. 2004. Temperature dependence of the distribution of organochlorine compounds in the mosses of the Andean mountains. Environ. Sci. Technol., 38: 5386-5392.

GRIMALT, J. O., P. FERNANDEZ, L. BERDIE, R. M. VILANOVA, J. CATALAN, R. PSENNER, R. HOFER, P. G. APPLEBY, B. O. ROSSELAND, L. LIEN, J. C. MASSABUAU \& R. W. BATTARBEE. 2001. Selective trapping of organochlorine compounds in mountain lakes of temperate areas. Environ. Sci. Technol., 35: 2690-2697.

HE, J. Z., K. R. ROBROCK \& L. ALVAREZ-COHEN. 2006. Microbial reductive debromination of polybrominated diphenyl ethers (PBDEs). Environ. Sci. Technol., 40: 4429-4434.

HOP, H., K. BORGA, G. W. GABRIELSEN, L. KLEIVANE \& J. U. SKAARE. 2002. Food web magnification of persistent organic pollutants in poikilotherms and homeotherms from the Barents Sea. Environ. Sci. Technol., 36: 2589-2597.

KAUPP, H. \& M. S. MCLACHLAN. 1999. Atmospheric particle size distributions of polychlorinated dibenzo-p-dioxins and dibenzofurans (PCDD/Fs) and polycyclic aromatic hydrocarbons (PAHs) and their implications for wet and dry deposition. Atmos. Environ., 33: 85-95.

KICKLIGHTER, C. E., J. KUBANEK \& M. E. HAY.
2004. Do brominated natural products defend marine worms from consumers? Some do, most don't. Limnol. Oceanogr., 49: 430-441.

KIDD, K. A., R. H. HESSLEIN, B. J. ROSS, K. KOCZANSKI, G. R. STEPHENS \& D. C. G. MUIR. 1998. Bioaccumulation of organochlorines through a remote freshwater food web in the Canadian Arctic. Environ. Pollut., 102: 91-103.

MACKAY, D. 1982. Correlation of bioconcentration factors. Environ. Sci. Technol., 16: 274-278.

RIBES, A., J. O. GRIMALT, C. J. T. GARCIA \& E. CUEVAS. 2002. Temperature and organic matter dependence of the distribution of organochlorine compounds in mountain soils from the subtropical Atlantic (Teide, Tenerife Island). Environ. Sci. Technol., 36: 1879-1885.

SIMONICH, S. L. \& R. A. HITES. 1995. Global distribution of persistent organochlorine compounds. Science, 269: 1851-1854.

TEUTEN, E. L., L. XU \& C. M. REDDY. 2005. Two abundant bioaccumulated halogenated compounds are natural products. Science, 307: 917-920.

THOMANN, R. V. 1981. Equilibrium model of fate of microcontaminants in diverse aquatic food chains. Canadian Journal Aquatic Science, 38: 280-296.

VIVES, I., J. O. GRIMALT, J. CATALAN, O. R. BJÖRN \& R. W. BATTARBEE. 2004. Influence of altitude and age in the accumulation of organochlorine compounds in fish from high mountain lakes. Environ. Sci. Technol., 38: 690698.

VONDERHEIDE, A. P., S. R. MUELLER-SPITZ, J. MEIJA, G. L. WELSH, K. E. MUELLER, B. K. KINKLE, J. R. SHANN \& J. A. CARUSO. 2006. Rapid breakdown of brominated flame retardants by soil microorganisms. J. Anal. At. Spectrom., 21: 1232-1239.

WANIA, F. \& D. MACKAY. 1993. Global fractionation and cold condensation of low volatility organo-chlorine compounds in Polar Regions. Ambio, 22: 10-18.

WANIA, F. \& D. MACKAY. 1996. Tracking the distribution of Persistent Organic Pollutants. Environ. Sci. Technol,. 30: A390-A396.

WANIA, F. \& J. N. WESTGATE. 2008. On the mechanism of mountain cold-trapping of organic chemicals. Environ. Sci. Technol., 42: 9092-9098.

WHO. 2003. Health risks of persistent organic pollutants from long-range transboundary air pollution. World Health Organization/IPCS: 1-274. 